\title{
Peripheral hypothyroidism
}

INSERM

\section{Source}

INSERM. (1999). Orphanet: an online rare disease and orphan drug data base. Peripheral hypothyroidism. ORPHA:226310

Peripheral hypothyroidism is a type of permanent congenital hypothyroidism (see this term), a permanent thyroid hormone deficiency that is present from birth, that results from peripheral defects in thyroid hormone metabolism. 